\title{
Occurrence of internal cavity in pineapple fruits in the state of Acre, Brazil
}

\author{
Rogério RitzingeR*, Cecilia Helena Silvino Prata Ritzinger
}

Embrapa Cassava \& Fruits, PO Box 007, 44.380-000 Cruz das Almas, Bahia, Brazil rogerio@cnpmf.embrapa.br
${ }^{*}$ Correspondence and reprints

Fruits, 2004, vol. 59, p. 215-218 (C) $2004 \mathrm{Cirad} /$ EDP Sciences All rights reserved DOI: $10.1051 /$ fruits:2004020

RESUMEN ESPAÑOL, p. 218

\section{Occurrence of internal cavity in pineapple fruits in the state of Acre, Brazil.}

Abstract - Introduction. Our work aimed at reporting the occurrence of an anomaly in pineapple fruit in the state of Acre. Materials and methods. Fruit observations were accomplished in the pineapple experimental area of Embrapa Acre, in Rio Branco, AC, Brazil, from 1987 to 1998. Results and discussion. Typical symptoms of the studied anomaly were observed in the varieties Pérola, Quinari and Abacaxi de Tarauacá: an early yellowing of the skin of the superior half of the fruit was noted, while the skin of the lower half retained its green color, as if the fruit was not ripe yet. In the interior of the fruit, a cavity or crack was present in the area of the main axis. No plant pathogenic organism was isolated from the cavity inside the fruits. Also, it was not possible to relate the occurrence of abnormal fruits with climatic factors, considering that fruit with normal ripening of the same varieties were picked at about the same time from nearby pineapple plants. The occurrence of fruit with abnormal ripening was not observed in other pineapple varieties, such as Rio Branco, Cabeça-de-Onça and SNG-3, cultivated in Acre. Conclusions. It was not possible to associate the anomaly with biotic or non-biotic factors. Thus, it could be of physiological cause.

\section{Brazil / Ananas comosus / varieties / fruit / functional disorders}

\section{Observation de cavités internes dans certains ananas cultivés dans l'état d'Acre au Brésil.}

Résumé - Introduction. Nos travaux ont cherché à étudier l'occurence d'une anomalie présente dans certains ananas de l'état d'Acre (Brésil). Matériel et méthodes. Des observations de fruits ont été poursuivies dans une parcelle expérimentale d'ananas de l'Embrapa, à Rio Branco, (Acre, Brésil), de 1987 à 1998. Résultats et discussion. Des symptômes typiques de l'anomalie étudiée ont été observés chez les variétés Pérola, Quinari et Abacaxi de Tarauacá : un jaunissement précoce de la peau a été noté dans la moitié supérieure du fruit, alors que la peau de la moitié inférieure restait verte, comme si le fruit n'était pas encore mûr. À l'intérieur du fruit, apparaissaient soit une cavité, soit une fente, localisées dans le secteur de l'axe principal. Aucun organisme pathogène du plant n'a été isolé dans ces cavités internes. De plus, il n'a pas été possible de relier l'observation de fruits anormaux avec des facteurs climatiques, car des fruits de mêmes variétés et de maturation normale ont pu être cueillis à peu près en même temps sur des plants voisins. Par ailleurs, des fruits présentant ces symptômes de maturation anormale n'ont pas été observés dans d'autres variétés d'ananas, telles que Rio Branco, Cabeça-de-Onça et SNG-3, cultivés dans l'état d'Acre. Conclusion. L'anomalie observée n'a pu être reliée à l'action d'un facteur biotique ou abiotique. Elle serait donc d'origine physiologique.

Brésil / Ananas comosus / variété / fruit / trouble fonctionnel 


\section{Introduction}

From planting to harvesting, constant inspection is recommended in crops to detect the possible occurrence of diseases that may often become epidemic, causing the total loss of the culture. A fast and efficient diagnosis can contribute to the decrease in costs and decrease in losses in production. Signs or a causal agent's symptoms basically allow one to recognize the manifestation of diseases. However, there is not always association with biotic agents. Sometimes, nonbiotic agents can promote symptoms similar to diseases caused by biotic agents, such as nutritional deficiency, drought stress, climatic conditions not favorable to the culture, etc. [1].

The pineapple [Ananas comosus (L.) Merr.] is cultivated in the state of Acre, Brazil, being most of the time an important source of profit for small farmers. A very high diversity of varieties is observed in the area. Embrapa Acre carried out collections in the whole state, forming a bank of pineapple germplasm, and the characterization of the genotypes based on botanical agronomic characters [2, 3]. Some diseases and pests were identified without, however, constituting limiting factors for the culture. The internal browning of the fruits, also known as fruitlet core rot caused by Penicillium funiculosum, and the black rot caused by Chalara paradoxa were observed in some varieties. However, up to the present evaluation, the fruitlet core rot caused by Fusarium moniliforme was not observed. These diseases epidemiology is very much related to the conditions of rainy periods followed by dry periods [4]. The internal browning, characterized by the appearance of a translucent spot in the flesh, is related to the exposition of the fruits to low temperatures. Therefore, its cause is non-biotic [4].

From 1987 to 1998, an anomaly was detected in the pineapple varieties in Acre. Some of them were more affected than others. The basic external symptom was an early and irregular ripening; usually, the lower half of the fruit retained its green skin. On the superior half, a yellowing was observed (figures 1-3). When a longitudinal cut was made in these fruits, a cavity or crack was observed in the main axis. This internal cavity did not extend to the exterior of the fruit. A darkening accompanied the entire cavity and extended to a few centimeters inside the flesh, but it basically followed the main axis of the fruit. Sometimes, depending on the size of the fruit, and of the intensity of the internal symptoms, there was just a small horizontal cavity (figures 4,5 ). Therefore, the purpose of this study was to investigate and to establish the etiology of this anomaly in the affected fruits.

\section{Materials and methods}

The observations were accomplished in the pineapple germplasm bank of Embrapa Acre. In 1987, the pineapple germplasm bank consisted of 16 genotypes, mostly local varieties of the species Ananas comosus. The anomaly - fruits with symptoms of early and irregular ripening - was only observed in some of the genotypes of this germplasm bank. The fruits were collected in the experimental plots and taken to the Plant Pathology Laboratory of Embrapa Acre for a routine exam of diagnosis. In the plots where the presence of the anomaly was observed, some fruits not showing the anomaly were also sampled, for verification of the presence of internal cracks or cavities.

Laboratory tests were accomplished to discover the presence of any biotic agents associated with the symptoms:

- Wet chamber test: fragments of the darkened tissue of the internal cavity of the fruit were taken to a covered glass plate, in aseptic conditions, to force the growth of a possible pathogen and were observed daily for a period of ( 4 to 5 ) days;

- Potato trap test: fragments of the infected tissue were placed on a cut potato, left at room temperature for a period of $48 \mathrm{~h}$, inside a covered glass plate, under a sterilized damp paper towel, and observed daily;

- Isolation on potato dextrose agar medium: fragments of the infected tissue were aseptically placed in Petri dishes, with BDA culture medium, and left to incubate for a period of $48 \mathrm{~h}$. The observations were carried out 
daily, under a stereoscope and composed microscope;

- Test for bacterial exudate: small fragments of the darkened tissue and of the healthy tissue were placed on a slide with sterilized water. The observations were carried out immediately, under a composed microscope, to verify possible bacterial exudate.

\section{Results and discussion}

No plant pathogenic organism or biotic agent was isolated using the traditional methods of diagnosis. Fruit with anomalies did not have any odor. Fruit not showing the external symptoms of irregular ripening did not have internal cracks and darkening.

In the pineapple experimental area, the symptoms appeared at random in the varieties Pérola, Quinari and Abacaxi de Tarauacá, and the spreading or progress of the anomaly was not verified in neighboring plants. Only a few plants, in the same experimental plot, had symptoms of early ripening with an internal crack. Extreme climatic variations that could prevent the culture from completing its cycle were not observed. At the end of the cycle, the plants with fruit without symptoms, close to the plants with the anomaly, had normal ripening, with no internal cracks. Therefore, it is suggested that the observation of the anomaly is not a result of climatic variation.

All the plants received NPK fertilization in the periods and amounts determined by research; however, only a few plants had the anomaly. Soil fertility spots were not observed in the area, through the development of the anomaly in neighboring plants; however, studies on lacking nutrients were not done.

During the evaluation period, the anomaly was not observed in other pineapple varieties, such as 'Rio Branco', 'Cabeça-deOnça', and 'SNG-3', which have been recommended for planting in Acre.

\section{Conclusions}

An anomaly in pineapple fruits, characterized by irregular ripening and the presence of an internal cavity, was observed in the varieties Pérola, Quinari and Abacaxi de Tarauacá in the Acre State, Brazil. It was not possible to associate the anomaly with biotic or non-biotic factors; it was possibly of physiological cause.

\section{References}

[1] Fox R.T.V., Principles of diagnostic techniques in plant pathology, CAB Int., Wallingford, UK, 1993, $213 p$.

[2] Matos A.P. de, Doenças e seu contrôle, in: Cunha G.A.P. da, Cabral J.R.S., Souza L.F. da (Eds.), O abacaxizeiro. Cultivo, agroindústria e economia., Embrapa Comunicação para transferência de Tecnologia, Embrapa Mandioca e Fruticultura, Brasilia, Brazil, 1999, pp. 269-305.

[3] Ritzinger R., Recomendação de cultivares de abacaxi para o estado do Acre, Embrapa / CPAFAC, Brasilia, Brazil, 1992, 4 p. (folder).

[4] Ritzinger R., Avaliação e caracterização de abacaxi no Acre, Embrapa / CPAFAC, Bol. Pesqui. 3, Brasilia, Brazil, 1992, 28 p.
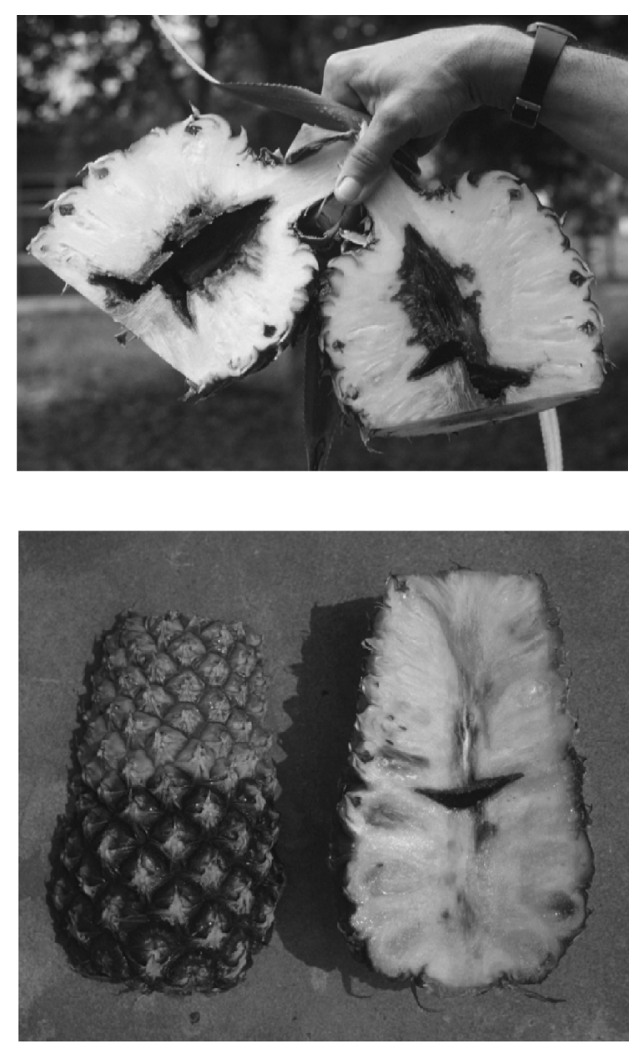

Figure 4.

Internal cavity of an Abacaxi de Tarauacá fruit showing darkening in the central axis, sometimes with horizontal extension.

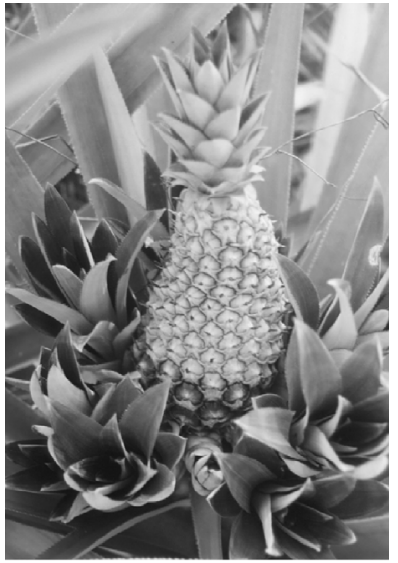

Figure 3.

Symptoms of early and irregular ripening in a pineapple fruit of Pérola variety (Acre, Brazil).

Figure 5.

Internal cavity of a Quinari fruit showing darkening in the central axis, sometimes with horizontal extension. 


\section{La ocurrencia de cavidad interna en frutos de piña en el estado de acre, Brasil.}

Resumen - Introducción. Este trabajo informa sobre la ocurrencia de una anomalía en frutos de piña en el Estado de Acre. Material y métodos. Las observaciones fueran realizadas en el área experimental de piña de la Embrapa Acre, en Río Branco, AC, de 1987 a 1998. Resultados y discusión. Se observaron síntomas típicos de la anomalía en las variedades Pérola, Quinari y Abacaxi de Tarauacá, que consistieron en un amarilleo precoz de la cáscara en la mitad superior del fruto, mientras que en la mitad inferior la cáscara permanecía con el color verde, como si el fruto no estuviera todavía maduro. En el interior del fruto se observó la presencia de una cavidad o hendidura en el área del eje principal. Ningún organismo fitopatogénico se aisló de esa cavidad en el interior de los frutos. Tampoco ha sido posible relacionar la incidencia de frutos anormales con los factores climáticos, desde que frutos con madurez normal, de las mismas variedades, fueron recolectados en el mismo tiempo desde plantas de piña cercanas aquellas que presentaban la anomalía. No se observó la incidencia de frutos con madurez anormal en otras variedades de piña indicadas para aquella região, tales como Rio Branco, Cabeça-de-Onça y SNG-3. Conclusión. No se pudo relacionar la anomalía observada con factores bioticos o abioticos. Su origen probablemente sea fisiológico.

\section{Brasil / Ananas comosus / variedades / fruto / trastornos funcionales}

To access this journal online: www.edpsciences.org 